\title{
Komunikasi Antarpribadi Ibu Dalam Mendidik Anak Berprestasi Akademik (Studi Kasus Pada Ibu Yang Berprofesi Sebagai Guru Bimbingan Konseling Yang Tergabung di Musyawarah Guru Bimbingan Konseling di Kabupaten Kuningan-Jawa Barat dalam Mendidik Anak Berprestasi Akademik Tahun 2016)
}

\author{
Tria Islamiyati \\ Alumni Magister Ilmu Komunikasi Pascasarjana Unisba \\ e-mail:dnarsizu@gmail.com
}

\begin{abstract}
Abstrak. Komunikasi Antarpribadi di dalam keluarga merupakan tempat yang penting bagi setiap orang untuk bersosialisasi. Keluarga dengan segala permasalahannya mampu menumbuhkan rasa kebersamaannya bagi para anggotanya. Oleh karena itu, penting bagi sebuah keluarga dalam kebersamaannya menumbuhkan rasa saling memiliki. Orangtua khususnya ibu yang memilih untuk bekerja, tidak dapat lepas dari tanggungjawabnya sebagai pendidik utama bagi anaknya agar proses belajarnya tetap berlangsung dengan terarah. Dengan komunikasi Antarpribadi yang efektif diharapkan terjalin harmonisasi antara ibu yang berprofesi sebagai guru konseling dengan anak yang berprestasi akademik. Penelitian di lakukan di Kabupaten Kuningan Provinsi Jawa Barat. Metode penelitian yang digunakan adalah studi kasus. Pengerjaan studi kasus mencakup suatu situasi yang secara keseluruhan berbeda. Dalam melakukan observasi terhadap kegiatan, peneliti mencampuri dunia subjek yang akan diselidiki. Penelitian ini mencoba menjawab tentang 1). Karakteristik komunikasi Antarpribadi Ibu dalam mendidik anak berprestasi akademik, 2) Penggunaan media komunikasi Antarpribadi Ibu dalam mendidik anak berprestasi akademik, 3) Faktor pendukung komunikasi Antarpribadi Ibu dalam mendidik anak berprestasi akademik. 4) Alasan Kompetensi Komunikasi Antarpribadi Ibu menjadi faktor penting dalam mendidik anak berprestasi akademik. Hasil penelitian menunjukan bahwa dalam 1). Karakteristik komunikasi Antarpribadi Ibu dalam mendidik anak berprestasi akademik ditemukan 5 karakteristik, 2) Penggunaan media komunikasi Antarpribadi Ibu dalam mendidik anak berprestasi akademik ada yang menggunakan berbagai jenis media komunikasi serta diterapkan aturan dalam penggunaannya , 3) Faktor pendukung komunikasi Antarpribadi Ibu dalam mendidik anak berprestasi akademik ditemukan 4 faktor yaitu atraksi interpersonal, persepsi interpersonal, konsep diri dan hubungan. 4) Ditemukan 4 Alasan Kompetensi Komunikasi Antarpribadi Ibu menjadi faktor penting dalam mendidik anak berprestasi akademik.
\end{abstract}

Kata Kunci:komunikasi antarpribadi, ibu, anak, berprestasi,akademik

Abstract. Interpersonal communication within the family is an important place for everyone to socialize. Families with all the problems can grow a sense of togetherness for its members. Therefore, it is important for a family in togetherness to grow a sense of belonging. Parents, especially mothers who choose to work, can not be separated from the responsibility as the main educator for their children so that the learning process is still directed. With effective interpersonal communication is expected to be established harmonization between mothers who work as counseling teachers with children with academic achievement.The research was conducted in Kuningan Regency West Java Province. The research method used is case study. The work of a case study involves a whole different situation. In observing the activities, researchers interfere with the subject of the subject to be investigated. This research tries to answer about 1). Characteristics of Interpersonal Communication Mother in educating children with academic achievement, 2) Use of Interpersonal Communication media Mother in educating children with academic achievement, 3) Supporting factors of Interpersonal communication Mother in educating children with academic achievement. 4) Reasons for Interpersonal Communication Competence Mothers become an important factor in educating children with academic achievement. The results showed that in 1). Characteristics of interpersonal communication Mother in educating children academic achievement found 5 characteristics, 2) The use of communication media Interpersonal Mother in educating children academic achievement there are using various types of communication media and applied rules in its use, 3) Support factors Interpersonal communication Mother in educating children academic achievement Found 4 factors of interpersonal attraction, interpersonal perception, self concept and relationship. 4) Found 4 Reasons for Interpersonal Communication Competence Mother becomes an important factor in educating children with academic achievement.

Keywords: interpersonal communication, mother, child, achievement, academic 


\section{Pendahuluan}

Komunikasi antarpribadi yang terjadi antar anggota keluarga merupakan suatu hal yang sangat penting, khususnya antara orang tua dengan anak mengenai pendidikan. Komunikasi sebagai alat atau jembatan dalam menghubungkan antar sesama anggota keluarga. Peran ibu awalnya adalah sebagai istri, ibu dari anak-anaknya, mengurus rumah tangga, sebagai pengasuh, pendidik anakanaknya, dan sebagai salah satu kelompok dari peranan sosialnya serta sebagai anggota masyarakat dari lingkungannya. Akan tetapi, saat ini ibu telah berperan sebagai pencari nafkah tambahan bagi keluarganya. Berbagai kegiatan diluar rumah, dilakukan oleh para ibu. Semakin meningkat jumlah ibu bekerja (terutama di kota besar), semakin kompleks pula dinamika kehidupan seperti tuntutan finansial dan biaya pendidikan anak. Para ibu menjadi pekerja keras untuk dapat membantu memenuhi kebutuhan hidup keluarganya. Bentuk komunikasi yang satu ini sering kita menganggap bahwa komunikasi harus terjadi tatap muka. Namun, seiring perkembangan teknologi, media komunikasi banyak bermunculan dan sangat membantu. Komunikasi yang dilakukan oleh para guru BK sering menggunakan teknologi. Dengan demikian, komunikasi
Antarpribadi mengalami pergeseran, yang sebelumnya kita mengenal karakteristiknya adalah tanpa media saat ini terjadi evolusi menjadi bermedia atau menggunakan media (mediated). Meskipun tatap muka lebih baik dari segala bentuk komunikasi, hadirnya media harus diakui telah mengubah cara berkomunikasi dan memberikan kontribusi besar terhadap hubungan Antarpribadi ibu-ibu bekerja dalam mendidik anak berprestasi ini.

Fenomena komunikasi yang terjadi antara ibu-ibu konselor di MGBK Kabupaten Kuningan dalam mendidik anak yang berprestasi yang terjadi begitu akrab, demokratis apalagi mengenai pendidikan. Karena disela-sela kesibukan ibunya yang bekerja tetap dapat memotivasi anaknya dalam belajar dan memberikan bimbingan atau pengajaran kepada anaknya, serta ketatnya pengawasan dari para ibu bekerja kepada anaknya untuk belajar di rumah. Anak-anak dapat mengatasi kesulitan dan hambatan dalam belajarnya, akibat ibunya yang bekerja dapat memperhatikan segala kebutuhan anaknya dalam belajar, yang pada akhirnya pun anak menjadi semangat dalam belajar karena terpenuhinya dorongan atau dukungan dari orang tua itu sendiri. 


\section{Pembahasan}

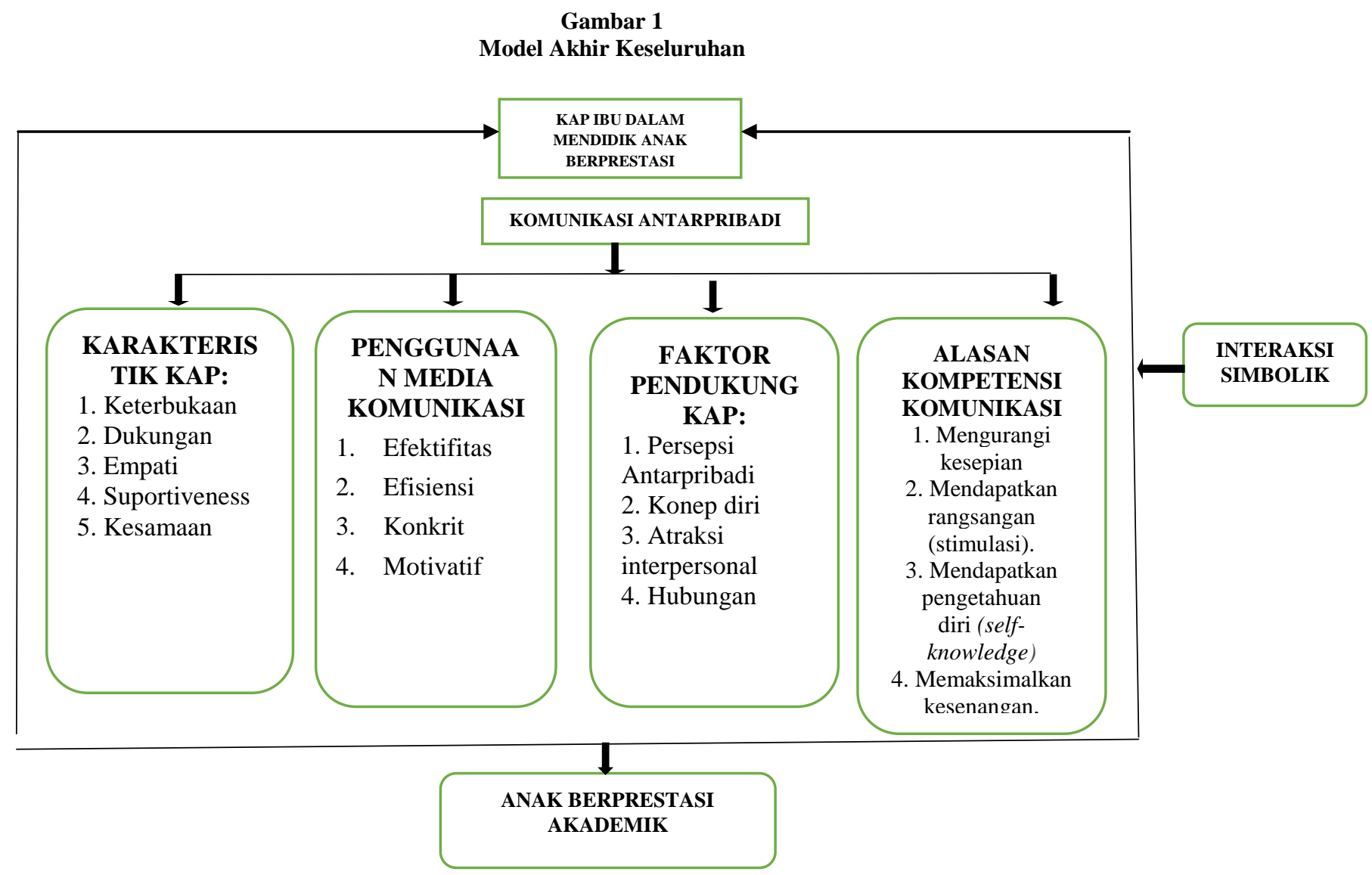

\section{a. Karakteristik Komunikasi Antarpribadi}

Dari hasil temuan peneliti, terlihat adanya komunikasi transaksional, yaitu proses pengiriman dan penerimaan pesan yang berlangsung secara terus menerus dalam sebuah episode komunikasi. Kata transaksi selalu mengacu pada proses pertukaran dalam suatu hubungan. Yang dipertukarkan adalah pesanpesan baik verbal maupun nonverbal. Model komunikasi transaksional berarti proses yang terjadi bersifat kooperatif, pengirim dan penerima sama-sama bertanggung jawab dampak dan efektivitas komunikasi yang terjadi. Tidak ada satupun yang tidak dapat dikomunikasikan. Dalam komunikasi antara ibu dan anak ini merupakan upaya untuk mencapai kesamaan makna. Terlihat dari penawaran reward yang diberikan.

Dari hasil wawancara juga ditemukan beberapa kegiatan ibu dan anaknya ketika berada di luar rumah. Para key informant tetap menanyakan kegiatan anak-anaknya melalui fasilitas handphone. Ini menjadi salah satu ciri terbentuknya dukungan komunikasi. Bentuk dukungan yang sederhana seperti itu, akan membuat anak merasa senang dan makin bersemangat ketika di berikan perhatian oleh orangtuanya. Menjaga hubungan Antarpribadi dengan dukungan antara satu sama lainnya merupakan kunci kesuksesan hubungan. Para key informant dan anaknya yang membangun hubungan dengan dukungan komunikasi, tentu saja berbeda dengan hubungan yang tidak dilandasi oleh dukungan. Dukungan membuat orangtua maupun anak akan merasa dihargai dan diakui dalam lingkungan keluarganya. Dukungan akan melahirkan keterbukaan dan kejujuran dari masing-masing individu yang membangun hubungan Antarpribadi, 
Peneliti melihat, ada beberapa usaha dan kemampuan sang ibu untuk menempatkan dirinya pada posisi atau peranan anaknya. Dalam proses belajar anak di Sekolah, tentutlah akan ditemui permasalahan dan hambatan. Seperti, hasil nilai ulangan yang kurang baik, tidak cocok dengan cara belajar guru di Sekolah, dll. Pada saat itu, peran ibu sangatlah di perlukan. Anak mengharapkan kepekaan orangtua untuk senantiasa membantu dan memberi dukungan kepada anak dalam memecahkan permasalahan yang ada. Pada akhirnya, ketika orangtua memiliki kepekaan yang baik dalam berkomunikasi dengan anak, maka belajar anak pun akan baik dan melaksanakannya dengan teratur, disiplin dan efesien.

Peneliti melihat para key informant secara emosional maupun intelektual mampu memahami apa yang dirasakan dan dialami anaknya dalam proses belajar. Ibu tidak mendoktrin anaknya sesuai apa yang dia inginkan, betul-betul menjadikan anak sebagai sahabat belajar. Dengan komunikasi yang bersifat empati inilah dapat berjalan dengan komunikatif. Salah satu bentuk empati yang ditunjukkan oleh key informant kepada anak adalah dengan membimbing belajar anak dan melatih melakukan pekerjaan rumah yang diberikan Guru di Sekolah. Anak membutuhkan perhatian ibu dalam proses belajar di sekolah, hal ini ditujukkan agar anak terlatih kemandirian dan kepercayaan akan kemampuannya belajarnya dan terbentuk pola komunikasi yang efektif.

Selain orang tua, anak juga memiliki pandangan atau penilaian terhadap ibunya yang berprofesi sebagai guru BK. Meskipun anak menilai orang tua memiliki profesi yang positif, anak mengharapkan komunikasi tetap berjalan, adanya perhatian orang tua, sesibuk apapun pekerjaan di kantor. Ibu yang bekerja sering dianggap tidak berhasil dalam mendidik anak-anaknya, termasuk masalah sikap anak. Orang menilai, kegagalan dalam mendidik anak salah satu penyebabnya adalah karena ibunya sibuk berkerja sehingga anak tidak dapat diperhatikan, termasuk dalam perkembangan sikap anak. Namun demikian, tidak semua anggapan itu benar karena para key informant tetap bisa terus memotivasi dan memberikan dukungan kepada anaknya dalam hal belajar. Key informant memahami bahwa Motivasi sabagai faktor dalam (batin) berfungsi menimbulkan, mendasari dan mengarahkan perbuatan belajar. Motivasi dapat menentukan baik tidaknya dalam mencapai tujuan, sehingga semakin besar motivasinya akan semakin besar kesuksesan belajarnya. Seorang anak yang besar motivasinya akan giat berusaha, tampak gigih, tidak mau menyerah dan giat membaca buku-buku untuk meningkatkan prestasinya. Sebaliknya mereka yang motivasinya lemah, tampak acuh tak acuh, mudah putus asa, perhatianya tidak tertuju pada pelajaran, suka menggangu kelas dan sering meninggalkan pelajaran. Akibatnya mereka banyak mengalami kesulitan belajar.

Begitu pentingnya bentuk empati ini dalam sebuah bentuk komunikasi antarpribadi anak dan orantua. Karena, Peran orang di sekitar anak sangat di butuhkan dalam proses perkembangan emosinya. Baik itu orangtua, guru, teman bermain ataupun teman sekolahnya. Demikian pula lingkungan tempat anak itu tumbuh juga penting. Bagi seorang anak, apabila orangtuanya tidak tanggap adalah sebuah tanda bahaya bagi masa depannya. Karena pertumbuhan dan perkembangannya adalah tanggung jawab orangtuanya, bukan hanya dirinya sendiri.

\section{b. Media Komunikasi}

Komunikasi Antarpribadi sudah banyak mengalami pergeseran, saat ini terjadi evolusi menjadi bermedia (menggunakan media). Meskipun tatap muka lebih baik dari segala bentuk komunikasi, hadirnya media harus diakui bahwa telah mengubah cara orang 
berkomunikasi dan sudah memberikan kontribusi yang besar terhadap hubungan Antarpribadi. Misalnya, ketikan para key informant telat pulang ke Rumah karena ada kerjaan di Sekolah atau sekedar memantau keadaan anaknya sehingga memerlukan media sebagai sarana. Selain HP, media komunikasi Antarpribadi dapat menggunakan cybermedia/ media baru (new media) menurut McQuail dalam bukunya "Mass Communication Theory", media baru meliputi dunia maya yang akhir-akhir ini digandrungi oleh banyak khalayak masyarakat. Seperti, Facebook, twitter, video call, telecofrence dan lainnya.

Peneliti melihat fenomena para key informant berkomunikasi dengan anaknya menggunakan media tentu sudah tidak asing lagi. Adanya evolusi terhadap gaya komunikasi Antarpribadi tentu saja tidak menjadi permasalahan karena komunikasi adalah ilmu yang dinamis. Yang terpenting adalah bagaimana agar tujuan dari komunikasi Antarpribadi tersebut dapat tersampaikan. Yaitu membangun dan membina hubungan Antarpribadi. Perkembangan ilmu pengetahuan dan teknologi telah membawa perubahan yang sangat signifikan terhadap berbagai dimensi kehidupan manusia, baik dalam bidang ekonomi, sosial, budaya, dan pendidikan.

\section{c. Cara Penggunaan Media Komunikasi Antarpribadi}

Salah satu usaha key informant adalah dengan menggunakan media pembelajaran sebagai sumber-sumber belajar anak-anaknya. Dari pernyataan di atas dapat disimpulkan bahwa media komunikasi dan pembelajaran adalah sarana pendidikan yang dapat digunakan sebagai perantara dalam proses pembelajaran untuk mempertinggi efektifitas dan efisiensi dalam mencapai tujuan pengajaran. Dalam pengertian lebih luas media pembelajran adalah alat, metode dan teknik yang digunakan dalam rangka lebih mengefektifkan komunikasi dan interaksi antara pengajar dan pembelajar dalam proses pembelajaran di kelas. Pengertian media secara lebih luas dapat diartikan manusia, benda atau peristiwa yang membuat kondisi siswa memungkinkan memperoleh pengetahuan, ketrampilan atau sikap (Basyiruddin Usman, 2002: 127).

Dengan demikian dapat dikatakan bahwa penggunaan media Komunikasi bukan sekedar upaya untuk membantu key informant dalam mendidik, tetapi lebih dari itu sebagai usaha yang ditujukan untuk memudahkan siswa dalam pelajaran. semaksimal mungkin untuk membantu lancarnya bidang tugas yang diemban untuk kemajuan dan meningkatkan kualitas peserta didik.

Penulis melihat gambaran penggunaan media komunikasi oleh key informant untul anak-anaknya sangat dibatasi. Key informant paham dampak serius handphone bagi anak-anaknya. Maka, mereka sedapat mungkin berusaha untuk tetap mengontrol, memfilter konten dan memberikan ruang terbuka untuk anak dalam bermedia. Ini salah satu cara yang digunakan oleh key informant untuk menjaga prestasi belajar akademik anak-anaknya.

\section{d. Manfaat Media Komunikasi}

Pertama Efektifitas, mayoritas penggunaan media komunikasi oleh para key informant dalam mendidik anakanak berprestasi akademik karena dengan media komunikasi mempermudah kelancaran penyampaian informasi. Anak-anak dapat mengerjakan tugas di Sekolah, update informasi sains terbaru dan berita-berita dari belahan dunia lainnya, hanya dengan fasilitas internet di handphone ataupun computer maka lebih mudah mendapatkannya.

Kedua efisiensi, peneliti menemukan berbagai alasan dari para key informant tentang penggunaan media komunikasi ini sungguh bermanfaat ketika berada dalam jarak yang jauh dengan anak-anaknya. Dengan fasilitas telepon, video call telah mempercepat penyampaian informasi 
dan mudah mengontrol anak-anak meski tidak bersama-sama dalam satu waktu dan tempat yang sama.

$$
\text { Ketiga konkrit, dengan }
$$

menggunakan media komunikasi membantu key informant mempercepat isi pesan yang bersifat abstrak. Terakhir motivasi, dengan menggunakan media komunikasi lebih semangat melakukan komunikasi dengan anak-anaknya.

\section{e. Faktor Pendukung Komunikasi Antarpribadi}

Terlihat dari hasil temuan penulis, pernyataan para key informant memiliki Persepsi Antarpribadi yang baik. memberikan makna pada stimuli inderawi, atau menafsirkan informasi inderawi. Persepi antarpribadi adalah memberikan makna terhadap stimuli inderawi yang berasal dari seseorang (komunikan), yang berupa pesan verbal dan nonverbal. Ketika melihat anakanaknya memiliki kemampuan yang lebih dalam bidang A, para key informant terus menggalinya agar bakat tersebut berkembang baik. Mereka selalu mengajak diskusi anak-anaknya, membicarakan perihal cita-cita dan potensinya agar mampu berprestasi dalam bidang yang ia sukai. Kecermatan dalam persepsi antarpribadi akan berpengaruh terhadap keberhasilan komunikasi, seorang peserta komunikasi yang salah memberi makna terhadap pesan akan mengakibat kegagalan komunikasi. Selain memiliki antarpribadi yang baik, komunikator dalam hal ini ibu yang berprofesi sebagai guru BK telah memiliki Konsep diri, yang mampu mengatasi berbagai masalah anak-anaknya di sekolah perihal belajar. Terbukti, ketika si anak menemui kesulitan dalam hal pelajaran, sang ibu mampu memberikan semangat sekaligus solusi. Ini merupakan konsep diri yang positif, mampu memahami kondisi si anak. Menyadari, bahwa setiap orang mempunyai berbagai perasaan, keinginan dan perilaku yang tidak seluruhnya disetujui oleh masyarakat.
Dari hasil temuan peneliti, terbukti bahwa para key informant membentuk konsep diri yang baik dengan berbagai cara yaitu mencoba berpenampilan baik, rapih dalam hal berpakaian, bertutur dan bersikap. Hal ini juga berpengaruh sebagai konselor, dituntut harus selalu berpikiran tenang dan sabar dalam mengahadapi masalah dengan anak-anak di Sekolah. Konsep diri yang dibangun key informant ini dapat menjadi cerminan terhadap perilaku anak, karena Setiap anak pada dasarnya senang meniru. Hal ini terjadi karena salah satu proses pembentukan tingkah laku mereka diperoleh dengan cara meniru. Menghadapi kenyataan yang demikian, orang tua dan guru dituntut untuk bisa memberikan contohcontoh keteladanan yang nyataakan halhal yang baik. Memberikan contoh yang baik ini bisa dengan menunjukkan sikap, termasuk sikap bersemangat ketika mempelajari hal-hal yang baru, atau bagaimana orang tua menyikapi suatu hal.

Selain itu, peneliti melihat dari pernyataan para key informant, mereka selalu berusaha berpikiran positif ketika anaknya mengalami masalah dengan guru di Sekolah. Mereka menuturkan bahwa segala kesulitan belajar pasti mampu di hadapi, dan terus berusaha mencari media pembelajaran lain yang cocok dengan masalah yang dihadapi anak-anaknya.

Selanjutnya, faktor pendukung komunikasi Antarpribadi yang terlihat dari pernyataan para key informant yaitu Dalam hal menumbuhkan dan menjaga percaya diri anak, para ibu juga senantiasa memberikan waktu luang untuk berlibur saat weekend, memberikan sugesti positif saat menghadapi masalah belajar, disiplin dalam waktu belajar dan berkomitmen. Mendengarkan segala keluh kesah anakanak. Hal ini untuk mempererat hubungan Antarpribadi, anak-anak akan gembira dan selalu terbuka perihal sekolahnya. Karena, dari senin-jumat sudah banyak waktu, tenaga yang dihabiskan untuk sekolah dan weekend 
adalah waktu yang tepat untuk menghabiskan waktu bersama keluarga dan merefresh kembali energy yang adaSikap ibu yang senang mendengarkan anak bercerita tentang kegiatan di Sekolah dapat mencerminkan empati yang baik Antara keduanya. Hubungan komunikasi yang terjalin pun akan senantiasa kuat dan kokoh meski anak dan ibu memiliki kesibukan masing-masing.

\section{f. Alasan Kompetensi Komunikasi Antarpribadi}

Dari pernyataan diatas, para key informant telah kompeten dalam beradaptasi dengan kebiasaan anakanaknya, sehingga komunikasi yang mereka bangunpun sangat efektif. Mengingat tiap anak membawa tipe yang berbeda-beda, dan tugas sang ibu hanya menjadi fasilitator yang mengantarkan anak menuju keberhasilan dalam belajar dan berprestasi. Pada akhirnya, semua tindakan dalam kegiatan komunikasi para key informant ditentukan oleh tujuan komunikasi mereka. Tujuan komunikasi menjadi acuan utama untuk memilih perilaku yang sesuai. Jika tujuannya dalam percakapan dengan anak-anaknya adalah untuk memberikan dukungan emosional kepada anak, maka tidak efektif jika kita berbicara panjang lebar tentang pengalaman kita sendiri. Namun demikian, jika kita ingin agar anak-anak memahami kita dengan lebih baik, mungkin akan sangat efektif jika kita berbicara secara mendalam tentang kehidupan orangtuanya.

Selain itu, Yang terpenting mengapa para key informant harus kompeten dalam berkomunikasi antrapribadi adalah agar mampu untuk terlibat dalam perspektif ganda, yaitu mereka dapat memahami baik sudut pandang sendiri maupun perspektif, perasaan, keyakinan dan pikiran anakanaknya. Ketika menerapkan perspektif ganda, key informant memahami bagaimana orang lain berpikir dan merasakan mengenai masalah yang ada.
Untuk mencapai sebuah dialog yang tulus, key informant harus mampu menyadari bagaimana anak-anak memandang dirinya sendiri, situasi serta pikiran dan perasaannya sendiri. Key informant mungkin punya sudut pandang yang berbeda dengan orang tersebut, dan mungkin ingin mengekspresikan persepsinya, namun mereka juga ternyata memahami dan menghormati sudut pandang anaknya dalam proses belajar. Orang yang tidak bisa menghormati perspektif orang lain dapat disebut sebagai "egosentris". Mereka memaksakan persepsi mereka kepada orang lian dan menafsirkan pengalaman orang lain dari sudut pandang mereka.

Selanjutnya, latar belakang dibutuhkannya kompetensi komunikasi antarpribadi adalah pemantauan (monitoring), yang merupakan kemampuan untuk mengamati dan mengatur komunikasi key informant. Sebagian dari mereka mungkin kerap kali melakukan hal ini. Ketika membawakan sebuah topik sensitive kepada anak perihal belajarnya yang sedang menurun, key informant mengingatkan dirinya sendiri untuk tidak bersikap defensif dan tidak ingin membawanya ke dalam debat yang kontraproduktif. Pemantauan dapat dilakukan baik sebelum maupun selama interaksi. Ketika berkomunikasi, kita tetap waspada sambil menyunting (edit) pikiran kita sebelum diungkapkan kepada anak-anaknya. Komunikasi melalui media online oleh key informant dipilih cara yang sangat efektif untuk memantau komunikasinya. Mereka bisa menyimpan pesan, membaca kembali untuk melihat apakah pesan yang kita tulis benar-benar mengungkapkan tujuannya, dan mengeditnya sebelum mengirim kepada anak-anaknya. Kemampuan key informant untuk memonitor komunikasinya memungkinkan untuk beradaptasi dengan tindakan komunikasi dan mengukur efektifitas saat berinteraksi dengan anak-anaknya. Di buktikan dalam evaluasi hasil belajar 
anak-anak di saat waktu yang telah mereka sepakati. Ada yang mengevaluasi saat pergantian semester, saat selesai ulangan maupun ada yang tiap hari melakukannya.

Terakhir, alasan harus mencapai sebuah kompetensi antarpribadi adalah untuk menjaga komitmen agar senantiasa berkomunikasi yang efektif dan beretika. Komitmen ini mengharuskan key informant untuk meluangkan waktu dalam berkomunikasi secara etis dengan anakanaknya sebagai manusia yang unik. Meski separuh waktunya para key informant untuk bekerja, tapi tidak membuat mereka tersulut untuk berkomunikasi yang beretika. Ini berarti bahwa para key informant telah memperlakukan anak-anaknya sebagai pribadi yang unik dan berharga, dengan selalu tidak mengabaikan perasaan anakanaknya. Mereka juga menghormati apa yang diungkapkan anak-anaknya, bahkan jika itu berbeda dengan sudut pandang key informant.

Sebuah komitmen untuk komunikasi yang efektif dan beretika juga mengharuskan kita untuk menghoormati dan menghargai perasaan dan pikiran diri kita sendiri. Sebagaimana kita harus menghormati orang lain, kita juga harus menghormati diri kita dan perspektif kita sendiri.

Dalam hasil wawancara dengan para key informant, peneliti menemukan beberapa alasan di butuhkannya kompetensi komunikasi antarpribadi oleh ibu yang berprofesi sebagai guru bimbingan konseling. Kompetensi tersebut bisa sebagai penasihat, pemecah masalah, dan fasilitator. $\mathrm{N}$ amunyang akan dibahas dalam bab ini tentang latar belakang kompetensi komunikasi harus dimiliki oleh ibu selain karena tuntutan profesi. Peneliti menemukan alasan lain seperti : Menjaga hati anak yg sensitive, Suami meninggal, Jarak jauh dengan suami, Mengaplikasikan ilmu, Mencetak anak yg manfaat, shalih, cerdas ilmu\&agama, Untuk mengevaluasi belajar anak, Karakter anak yang berbeda, Sadar akan kunci keberhasilan,
Membantu menggapai cita-cita anak, Single Parent, Mencetak anak mandiri, Menjadikan ibu sebagai sahabat anak, Tuntutan profesi, Sadar akan tanggungjawab, Untuk Menumbuhkan komunikasi yang santun, terbuka, komunikatif, dan Banyak kasus anak yg bermasalah dalam keluarga,

Dari hasil temuan peneliti, ditemukan beberapa kondisi dari para key informan yaitu suami kedua informant telah wafat dan key informant 3 mengalami Long Distance Married Ini membuat para key informant ingin menjadikan anak-anaknya sebagai sahabat hingga masa tua nanti. Jadi, di butuhkanlah kompetensi komunikasi untuk terus memupuk hubungan antara ibu dan anak. Agar kelak anak-anaknya pun kelak ketika sudah dewasa tidak lantas meninggalkan ibunya sendirian. Ikatan batin dan komunikasi yang efektiflah yang mampu merekatkan ikatan ibu dan anak.

Kedua, Mendapatkan rangsangan (stimulasi). Manusia membutuhkan stimulasi. Jika kita tidak menerima stimulasi, kita mengalami kemunduran dan bisa mati. Kontak antarmanusia merupakan salah satu cara terbaik untuk mendapatkan stimulasi ini. Kita merupakan gabungan dari banyak dimensi yang berbeda-beda, dan semua dimensi kita membutuhkan stimulasi. Kita adalah makhluk intelektual, dan karenanya kita membutuhkan stimulasi intelektual. Kita membicarakan gagasan, mengikuti kegiatan dikampus, dan berdiskusi mengenai banyak hal. Dengan cara itu kita mengasah kemampuan penalaran, analitik, dan interpretasi kita. Dengan melakukannya, kita meningkatkan, mempertajam, dan mengembangkan kemampuankemampuan ini.

Dari hasil temuan peneliti, para key informant membutuhkan eksistensi diri tidak hanya dalam keluarga, namun tetap konsisten bertanggungjawab akan profesinya sebagai pendidik di Sekolah. Cara yang biasa dilakukan oleh para key informant untuk mendapatkan rangsangan dan upgrading diri yaitu 
dengan mengikuti berbagai seminar, pelatihan, dan berbagai kegiatan lainnya di MGBK Kab. Kuningan.

Ketiga,

Mendapatkan pengetahuan diri (self-knowledge), Sebagian besar melalui kontak dengan sesama manusialah kita belajar mengenai diri kita sendiri. Dalam diskusi tentang kesadaran-diri telah dijelaskan bahwa kita melihat diri sendiri sebagian melalui mata orang lain. Jika kawan-kawan kita meliha ita sebagai orang yang hangat dan pemurah, misalnya, barangkali kita juga akan memandang diri sendiri sebagai hangat dan pemurah. Persepsi-diri kita sangat dipengaruhi oleh apa yang kita yakini dipikirkan orang tentang diri kita.

Dari hasil pengamatan peneliti, ditemukan beberapa kondisi permasalahan antara ibu dan anak dalam hal belajar dan prestasi. Seperti, saat anak harus mengalami nilai dibawah $\mathrm{kkm}$ maka dengan kompetensi komunikasi antarpribadi ibu yang baik. Key informant berhasil tetap menjaga hati anak yang sensitive. Dengan menyadari bahwa, proses belajar di sekolah adalah proses yang sifatnya kompleks dan menyeluruh. Banyak orang yang berpendapat bahwa untuk meraih prestasi yang tinggi, seseorang membutuhkan IQ yang tinggi karena intelegensi merupakan bekal yang potensial yang akan memudahkan dalam belajar dan pada gilirannya akan menghasilkan prestasi belajar yang optimal. Namun, menurut hasil penelitian terbaru dibidang psikologi membuktikan bahwa IQ bukanlah satusatunya faktor yang mempengaruhi

C

\section{Kesimpulan}

a. Dari penelitian mengenai karakteristik komunikasi antarpribadi ibu yang berprofesi sebagai guru konseling dalam mendidik anak berprestasi ditemukan 5 temuan yaitu keterbukaan, dukungan, empati, kesamaan dan positiveness. prestasi belajar seseorang, tetapi ada banyak faktor lain yang mempengaruhi salah satunya adalah kecerdasan emosional.Terakhir, Memaksimalkan kesenangan, menimalkan penderitaan. Alasan paling umum untuk membina hubungan, dan alasan yang dapat mencakup semua alasan lainnya, adalah bahwa kita berusaha berhubungan dengan manusia lain untuk memaksimalkan kesenangan dan meminimalkan penderitaan. Para key informant perlu berbagi rasa dengan keluarga maupun orang lain mengenai nasib baik serta mengenai penderitaan emosi atau fisik. Barangkali kebutuhan yang terakhir ini bermula dimasa kanakkanak, ketika kita berlari mendekati ibu sehingga ibu kita dapat mengusap luka atau ikut menikmati kegembiraan kita. Sekarang tentu sulit untuk berlari mendekati ibu, karenanya kita mencari orang lain, umumnya kawan-kawan yang akan memberikan dukungan yang sama seperti yang pernah dilakukan ibu diwaktu yang lalu.

Dari sekian banyak temuan peneliti, inilah hasil akhir temuan yang diperoleh. Komunikasi antarpribadi yang dibangun oleh ibu dalam mendidik anak ini bertujuan agar anak-anaknya dapat menjadi generasi penerus yang berprestasi, cerdas, shalih dan shalihah yang bisa bermanfaat untuk sekitar. Hal ini tentu dapat meminimalisir kesulitan ataupun penderitaan bagi kehidupan anak-anaknya di kemudian hari. Bagi peneliti, hal-hal ini mustahil terwujud jika para key informant tidak memiliki keterampilan dalam mengasah kompetensi komunikasi antarpribadinya.

b. Para key informant menggunakan media komunikasi antarpribadi dalam mendidik anak-anaknya untuk tetap berprestasi akademik. Bisa dilihat dari beberapa jenis komunikasi yang digunakan, seperti: handphone, internet, youtube, facebook, televisi, whatsup, line, dan bbm. 
c. Peneliti melihat bahwa faktor pendukung komunikasi antarpribadi guru konseling dalam mendidik anak berprestasi adalah Persepsi Antarpribadi, Konep diri, Atraksi interpersonal, Hubungan. Dapat dilihat dari, persepsi interpersonal dari para key informant yang baik dalam berkomunikasi dengan anakanaknya dan konsep diri yang dibangun menjadi salah satu pilar yang membangun komunikasi antarpribadi ini berlangsung begitu efektif, anak semakin tumbuh minat belajar dan berprestasi akademik.

d. Ibu mampu berperan ganda. Selain itu,Yang dapat dilihat ketika key informant berkomunikasi dengan anaknya, mereka begitu mudahnya beradaptasi dengan berbagai tipe

\section{DAFTAR PUSTAKA}

Ascan, F.K. \& Anne, M.F. (2002, February). Family Communication. Communication Theory, 12(1), 70-91.

Arsyad, Azhar. 2002. Media Pembelajaran. Jakarta: PT Raja Grafindo Persada.

Alex Sobur. (2003). Psikologi Umum. Bandung: Pustaka Setia.

Alteza, M. \& Hidayati, L. N. Work family conflict pada wanita bekerja: Studi tentang penyebab, dampak, dan strategi coping. Universitas Negeri Yogyakarta.

Azwar, Syaifuddin. 1995. Sikap Manusia (Teori dan Pengukurannya), Pustaka Pelajar. Yogyakarta.

Akhyak,2005. Profil Pendidikan Sukses, (Surabaya : Elkaf.

Beebe, Steven A, Susan J. Beebe, Mark V. Redmond. 2005

Bungin, B. (2007). Penelitian kualitatif. Jakarta: Kencana Media Grup

Cangara, Hafied. 2005. Pengantar Ilmu Komunikasi. Jakarta: Raja Grafindo Persada.

Chaplin, J. P. (2008). Kamus Lengkap Psikologi.

Jakarta: PT Raja Grafindo. belajar anak. Sehingga kompetensi komunikasi antarpribadi menjadi faktor yang penting dalam mendidik anak berprestasi akademik dan ditemukan beberapa latar belakang mengapa kompetensi komunikasi antarpribadi ibu yang berprofesi menjadi guru konseling, yang menjadi faktor penting dalam mendidik anak berprestasi. Diantaranya: Mengurangi kesepian, Mendapatkan rangsangan (stimulasi), mendapatkan pengetahuan diri (self-knowledge), Memaksimalkan kesenangan, meminimalkan penderitaan.

DR. C. Asri Budiningsih, 2004. Belajar dan Pembelajaran. Penerbit Rinika Cipta, Yogyakarta. Hal. 39-40.

DeVito, J.A. (2007). Komunikasi antar manusia. Jakarta: Professional Books.

Effendy, O.U. (2007). Ilmu, teori, dan filsafat komunikasi. Bandung: PT. Citra Aditya Bakti.

Hurlock, Elizabeth B. (2011). Psikologi

Perkembangan: Suatu Pendekatan Sepanjang Rentang. Kehidupan. Jakarta : Erlangga.

Frank, R. \& Livingstone, K. E. (1999). Equal Balanced Parenting and The Involved Father New York: St. Martin's Press.

Friedman, M. 2010. Buku Ajar Keperawatan keluarga: Riset, Teori, dan Praktek. Edisi ke-5. Jakarta: EGC Komunikasi Interpersonal (Interaksi Keseharian).

Goleman, D. (2002). Working With Emotional Intelligence. Kecerdasan Emosi untuk Mencapai Puncak Prestasi. (Terjemahan Alex Tri Kantjono Widodo). Jakarta : PT. Gramedia Pustaka Utama.

Liliweri, Alo.2015. Komunikasi Antar Personal. Jakarta : Prenamedia Group. 
Moleong, L. J. (2007). Metodologi Penelitian Kualitatif Edisi Revisi. Bandung: PT Remaja Rosdakarya. Mulyana, Dedy.2005,Ilmu Komunikasi: Suatu Pengantar, bandung:Remaja Rosdakarya.

Mulyana, Deddy. 2004. Metodologi Penelitian Kualitatif. Bandung; PT Remaja Rosdakarya

Morissan. 2010. Psikologi Komunikasi.

Bogor : GHlmia Indonesia.

Omas Ihromi, Wanita Bekerja dan Masalah-masalahnya, dalam Toety Hearty Nurhadi dan Aida Fitalaya S. Hubeis (editor), Dinamika Wanita Indonesia seri 01: Multidimensional, Pusat Pengembangan Sumberdaya Wanita, Jakarta, 2000, hlm. 38.

Pawito. (2007). Penelitian komunikasi kualitatif. Yogyakarta: LkiS Pelangi Aksara Yogyakarta.

Rakhmat, Jalaluddin. 2008. Psikologi Komunikasi. Bandung: PT Remaja Rosdakarya.

Santrock, John W. (2007). Perkembangan Anak, edisi ke11 jilid 1. Penerbit Erlangga,. Jakarta.

Segrin, C. \& Flora, J. (2008). Family Communication. New Jersey: Laurence Erlbaum Associates.Inc

Santrock, J.W. 2007. Psikologi Pendidikan (edisi kedua). (Penerj. Tri Wibowo B.S). Jakarta: Kencana.

Sendjadja, S. Djuarsa.2004. Teori Komunikasi. Jakarta : Universitas Terbuka.

Sugiyono, Metode Penelitian Pendidikan: Pendekatan Kuantitatif, Kualitatif, dan R\&D, (Bandung:Alfabeta, 2010)

Santrock, J.W. (2007). Perkembangan Anak. Jilid 1 Edisi11. Jakarta:Erlangga
Sugiyo. 2005. Komunikasi Antarpribadi. Semarang: UNNES Press.

Sudjana, Nana.. 2005. Penilaian Hasil Proses Belajar.Bandung: Remaja Rosdakarya.

Syaiful Bahri Djamarah dan Aswan Zain. (2002). Strategi Belajar Mengajar. Jakarta: Rineka Cipta.

Usman, Basyirudin dan Asnawir. 2002. Media Pembelajaran. Jakarta: Delia Citra

Utama.

Vardiansyah, D. (2004). Pengantar ilmu komunikasi. Bogor: Pernerbit Ghalia Indonesia.

Wirjokusumo, I. \& Ansori. (2009). Metode penelitian kualitatif bidang ilmu-ilmu sosial humaniora: Suatu pengantar. Bandung: PT Remaja Rosdakarya

Wiryanto. 2004. Pengantar Ilmu Komunikasi. Jakarta: PT. Grasindo.

West, Richard dan Lynn $\mathrm{H}$. Turner.2008. Pengantar Teori Komunikasi. Jakarta: Salemba Humanika.

Sendjadja, S. Djuarsa.2004. Teori Komunikasi. Jakarta : Universitas Terbuka.

Supratiknya, A. 2006. Komunikasi antar pribadi : tinjauan psikologis. Yogyakarta: Kanisius.

Slameto. 2003. Belajar dan Faktorfaktor yang Mempengaruhinya. Jakarta: Rineka Cipta.

Supartono W, Drs. 2004. Ilmu Budaya Dasar. Jakarta: Ghalia Indonesia Wiryanto. 2004. Pengantar Ilmu Komunikasi. Jakarta: PT. Grasindo.

Wood, Julia T. 2010. Komunikasi Interpersonal : interaksi keseharian. Jakarta : Salemba Humanika. 